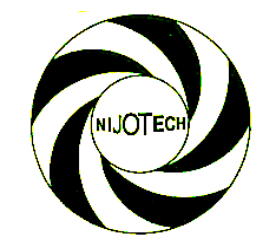

Nigerian Journal of Technology (NIJOTECH)

Vol. 39, No. 3, July 2020, pp. 665 - 679

Copyright(C) Faculty of Engineering, University of Nigeria, Nsukka

Print ISSN: 0331-8443, Electronic ISSN: 2467-8821

www.nijotech.com

http://dx.doi.org/10.4314/njt.v39i3.4

\title{
DELIVERING SUSTAINABLE TRANSPORT INFRASTRUCTURE PROJECTS (RAILWAY) IN NIGERIA: FRAMEWORKS, INDICATORS, METHOD AND TOOLS
}

\author{
0. M. Oraegbune ${ }^{1, *}$ and $0.0 . \mathrm{Ugwu}^{2}$ \\ 1, Dept of Civil Engineering, Modibbo Adama Univ. of TeChnology, Yola, Adamawa State, Nigeria

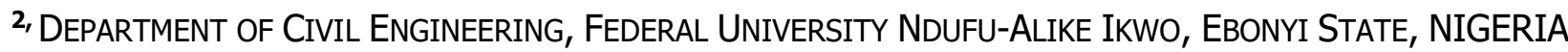
Email addresses: ${ }^{1}$ irokom0013june@gmail.com, ${ }^{2}$ onuegbuugwu@gmail.com

\begin{abstract}
This study presented the issue of railway transportation infrastructure sustainability which involves multi-dimensional view of sustainability criteria such as economy, environment and society with the problem of non-systematic method of assessment in Nigeria. The aim of this study is to ascertain the extent of practice of sustainability in railway transportation infrastructure projects through the frame work, methods, tools and identify infrastructure sustainability priority indicators amongst stakeholders. In this research, weighted sum model technique in multi-criteria decision analysis (MCDA), was used. This section formulates the mathematical model for computing the sustainability index (SI) using the Weighted Sum Model (WSM) which is structured in three steps. Also employed in the assessment is cognitive/reasoning map decision aid for infrastructure sustainability appraisal. This study also discussed the issue of key performance project indicators for transport infrastructure using sustainability appraisal in infrastructure projects (SUSAIP). Sustainability indicators are discoursed base on regional level(s), for example All-region represents cumulative results from the four regions. The result of the questionnaire based indicators validation by the stakeholders indicates that some indicators can easily be influence due to unexpected changes or regional priorities. Because of non-availability of systematic method of appraisal of sustainability criteria and priority indicators in practice level. This paper proposed gradual exploitation and collaborating decision frameworks for evaluation and mathematical foundation models. This method employed computational analysis in quantitative based decision-making crisp value and sustainability index for railway transport infrastructure projects assessment in Nigeria.
\end{abstract}

Keywords: Cognitive/reasoning map, key performance indicators, Sustainability criteria, sustainability assessment tools, transport infrastructure projects, and weighted sum model.

\section{INTRODUCTION}

Transportation infrastructure in Nigeria includes road and highways, railway, canal and navigable water ways, seaports and light houses, airports, mass transit systems, bicycle paths and pedestrian walkways and ferries. Transportation infrastructure is very essential for the economic and social development of all countries as well as for supporting regional and global co-operations and economies [1]. However, poor transport infrastructure and lack of access to safe and effective transport infrastructure, constrain development in many developing countries, especially the developing countries like Nigeria. These problems are exacerbated or exasperated by population growth and urbanization.

At our independence in 1960, Nigerians inherited a vibrant, buoyant flourishing and efficient system from the colonial administration. Although, the single track narrow-gauge network rain diagonally across the country, it was well able to haul all the agricultural products growth in the far north to the seaports at Lagos and Port Harcourt.

${ }^{*}$ Corresponding author, tel: +234-806- $910-8650$ 
Although, further development of the railways was abandoned in favour of road transport infrastructure by successive governments. Roads were expanded without any consideration of the attendants, effects such as road traffic accidents, environmental hazards (pollution, noise, dust etc), congestion, parking etc. Some highways were constructed parallel to railway lines resulting in competition rather than a complementary role between road and rail transport. The difference in allocation of funds for railway and road transportations by the government are shown here figure 1 and this trend still haunts railway development today in Nigeria [1]. Similarly, at independence in 1960, NRC had 257 locomotives, 339 carriages and 3885 freight wagons to serve an estimated population of about 88.5 million people [2]. The aim of this paper is to ascertain the extent of practice of sustainable transport infrastructure projects in Nigeria through framework, methods, tools and identify infrastructure sustainability priority indicators amongst stakeholders. While the significance of the study is to highlights our transportation infrastructure problems and promote more integrated thinking and consistent approach to enhance delivery of the sustainability agenda vis-àvis sustainable development in Nigeria.

There had been some local and international development plans to revitalize and sustains the railway system from 1978 to 199 . The initiatives included:

When the Indians took over (1978 - 1982), they achieved the mission objectives by rehabilitations of rail networking using advice from rail India Engineers, recover and maintain obsolete and disabled rolling stock. However, the abrupt termination of the jointventure made results short-lived. No sooner had the Indian experts left them, railway collapsed again. Gross operation inefficiency set in the railway infrastructure decayed rapidly and finances were deplorable. To bring the normality back to the railway system, Dr. Sammal Ogbemudia was appointed the Sole Administrator of the NRC by the Federal Government. Although, his tenure was short, it was eventful and remarkable. As soon as
Ogbumedia left the corporation, his future action programmes, including revitalization and development of railway facilities and infrastructure, improved services, self-supporting railway with new marketing strategy etc., were thrown overboard by successive administration [1, 2]. The CCECC and NRC rehabilitation project 1995 - 1999 signed agreement with government of Nigeria. China Civil Engineering Construction Corporation (CCECC) removed the 9 year vacuum created by the exit of Ogbumedia. The N86 million contracts was like a way of light in a dark turned $[1,2]$. The Chinese experts were expected to rehabilitate the existing rail networks, supply 50 locomotives, 150 coaches, 400 wagons and 20 rail buses and provide technical training for the NRC staff. However, the impact of the rehabilitation of this project could be noticed because when the Chinese Company (CCECC) withdrew, NRC could not sustain or continue with rehabilitation projects as scheduled [1, 2].

Because railways are very capital intensive, the Nigerian government should encourage competition by allowing private sector participation in ownership, funding and operations [2]. The author further stated that this will help intensify the effort to modernize or sustain railway infrastructure and services as we start the next Millennium. In his work, the author formulated that it will be much easier for private business than government to raise funds via the stock market, especially developing economies like Nigeria. Permitting private corporations and individuals to fund railway operations will usher in modern technologies in specialized areas like information technology, railway stock and locomotive manufacturing, rail network design etc. Moreover, it will encourage healthy competition between various companies, thereby offering the populace the best services along with options. It will create an environment for developed countries, such as Japan, USA and Canada etc., to invest in railway development in Nigeria which will enhance both railway development and economic growth of Nigeria.

Table 1: Evolution of Railway Major Contract Projects in Nigeria

\begin{tabular}{lll}
\hline S/No. & \multicolumn{1}{c}{ Description } & \multicolumn{1}{c}{ Dates } \\
\hline 1. & A contractual agreement between Nigeria and Rail India Technical Economic Services & $1978-1982$ \\
2. & Ogbemudia Revolution that turned around local rail point & $1989-1992$ \\
3. & The rehabilitation project with China Engineering Construction Corporation & $1995-1999$ \\
\hline
\end{tabular}


According to [4], there are few available avenues in most African countries for raising sufficient revenue to fund urban infrastructure, they are, however, restricted by their national governments to a narrow range of revenue.

According to his study, this has been the true state of railway funding by only government. The government has never encouraged partnering' whereby multi-national corporations could participate and invest in development of the rail transport infrastructure system. The author further suggested that private transport companies with strong financial base should be allowed to invest and participate in Nigeria's railway transport infrastructure business, alongside NRC. They should be encouraged to invest in the railway through the stock market to increase efficiency, regulating, adequacy, reliability and sustainability of railway services in Nigeria. According to [2], suggested that injection of private funds into the Nigerian railway infrastructure system will boost the Nigerian economy. Applied and sustained investment in railway network could pave the way for sustainable development of a sub-regional international railway corridor in West Africa early in the $21^{\text {st }}$ Century White Yang.

\section{CONCEPTUAL DEVELOPMENT OF SUSTAINABILITY AND SUSTAINABLE TRANSPORT}

The United Nations (UN) StockholimConference on the Human Environment in 1992 marked the first significant international meetings on how human activities were harming the environment and putting humans at risk. The UN Conference on Environment and Development (UNCED), also known as the Earth Summit, and held in 1992 in Rio de Janerio, Brazil, adapted agenda 21, this agenda was a statements of principles by more than 178 Governments and a comprehensive plan of action to be adopted global, nationally, and locally by organization of UN system and government in areas in which humans impact the environment. The Commission in Sustainable Development (CSD) was then created in 1992 to ensure effective follow-up of UNCED. The World Summit on Sustainable Development (WSSD) in Johannesburg, 2002, re-affirmed implementation of Agenda 21 [5]. The most widely accepted definition of sustainable development in general originated from the 1987 Brundland Report. The report defined sustainable development as development which meets the needs of the present without compromising the ability of future generations to meet their own needs" [6]. This definition according to [7], clearly implies that human beings and the natural environment have limited resources. Future generations will also need these resources to fulfill their own demands. Sustainable development is then the prudent use of these limited resources in ways that extends their use for future generations.

\subsection{Sustainable Transport Infrastructure and Three Development Pillars}

Currently, there is no roadmap definition for sustainable transport but the World Business Council for sustainable development defined sustainable transport as: the ability to meet society's need to move freely, gain access, communicate, trade and establish relationships without sacrificing other essential human or ecological values of today or in the future. But [8], defined sustainable transportation "the capacity of today's generation to meet today's transportation needs without comprising the capacity of future generation to meet their needs".

According to [9], so many definition has been proposed or suggested but the one recommended was the one selected by European Council of Ministers of transport [10], because it has a broad scope and recognized specific transportation issues. According to this definition, a sustainable transport system.

(i) Allows the basic access and development needs of individuals, companies and society to be met safety and in a manner consistent with human and ecosystem, health and promotes equity within and between successive generations.

(ii) Is affordable, operates fairly and effectively offers a choice of transport made and balanced regional development.

(iii) Limits emissions and waste within the planets ability to absorb them, uses renewable resources at or below their rates of generation, and uses non-renewable resources at or below the rates of development of renewable substitutes while minimizing the impact on the use of land and the generation of noise. 


\subsubsection{Transport and Sustainable Development Promontories}

There are three Sustainable Development Promontories of Transport namely: Economic; Social and Environmental Development(s).

\subsubsection{Transport and sustainable economic development}

Transport is crucial for economic growth and trade, both of which are high dependent on the transportation of people and goods. Almost no production can take place unless such inputs as raw materials, labour and fuel can be moved from different locations, neither can manufactured products be delivered to consumers nor a wide variety of services carried out.

\subsubsection{Sustainable Transport and Social Development}

Transport impacts on people's quality of life in many ways. The negative impacts are often obvious and can be very significant for the environment and people's wellbeing. They include air pollution, noise and vibrating caused by road, rail and air traffic, the loss of wildlife habitats and country side, the visual intrusiveness of roads and railways, and oil-spills on beaches [11]. These impacts occur at all levels of the life cycle of vehicles (passenger's cars, buses, trucks and train) and include vehicle production, operation and discarding $[1,11]$.

\subsubsection{Sustainable Transport and Environmental Issues}

Transport related activities have wide ranging and far reaching environmental impacts on natural resources, including air pollution, water pollution and impacts on hand. In addition, they also contribute to global warming and climate change as well as such other effects as local noise pollution and congestion as well as a range of public health problems $[1,11]$. (See Figure 1).

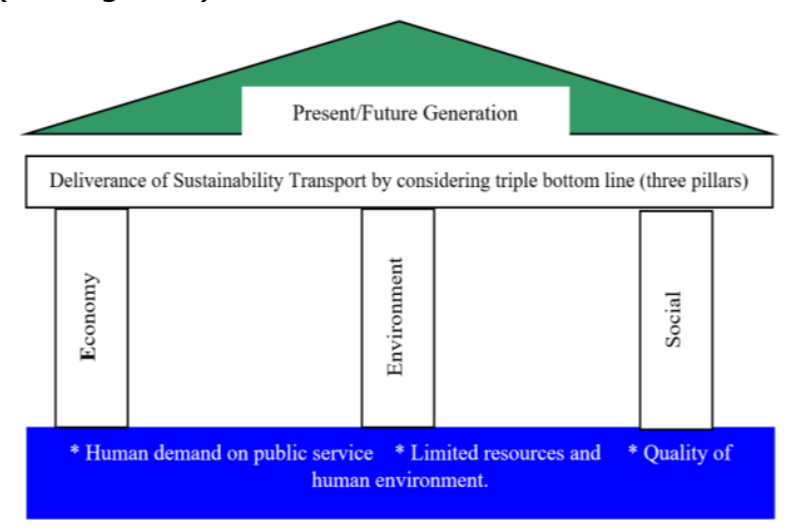

Figure 1: Three promontories of sustainable transport development Source: [1]

Table 2: Assessment Model for Sustainable Infrastructure Projects

\begin{tabular}{l} 
Sustainability Assessment Tools \\
Civil Engineering Quality Assessment \\
and Awards Scheme [12] UK; \\
\hline Project sustainability management \\
(PSM) guidelines developed by the \\
international federation of consulting \\
Engineers [13].
\end{tabular}

Key performance indicators for infrastructure sustainability [14]. Summary

* Aimed at improving sustainability in Civil Engineering and public realm projects by providing an incentive to clients, designers and contractors to adopt best environmental and social practices and therefore deliver more sustainable constructions.

* FIDIC PSM is based on a set of sustainability indicators that are derived directly from the United Nations Commission for Sustainable Development (UNCSD) list of sustainability themes which encompass all the main universal values and principle. It provides for a specific situation and context.

* These constructs/concepts incorporate internationally and accepted sustainability matrices such as economy, environment and society. It also incorporate other performance based indicators such as health and safety resource utilization and project management.

* AGIC Infrastructure sustainability rating scheme and associated tool is still in the early stage of development of sustainability categories and 27 sub-categories have been identified, covering the areas of project management and governance, economic performance etc.

Australia Green Infrastructure Council [15] Australia. 


\begin{tabular}{|c|c|}
\hline ols & \\
\hline $\begin{array}{l}\text { Defense Estate Sustainability Appraisal } \\
\text { Tool (DESAT) Developed by Australia } \\
\text { Ministry of Defense. }\end{array}$ & $\begin{array}{l}\text { This sustainability appraisal tool has been produced to help MOD } \\
\text { project managers, decision-making and construction to fulfill their } \\
\text { environmental objectives. }\end{array}$ \\
\hline $\begin{array}{l}\text { Sustainable Project Appraisal Routine } \\
\text { (SPeAR), developed by Australia } \\
\text { Consulting Company (ARUP). }\end{array}$ & $\begin{array}{l}\text { A design tool enabling companies and organizations to assess } \\
\text { their sustainability performance over time. The tool is applicable } \\
\text { to wide range of sections and to all levels of projects from } \\
\text { strategic policy development to individual project assessment. }\end{array}$ \\
\hline $\begin{array}{l}\text { VIC Roads sustainable roads } \\
\text { assessment (SRA), Developed by } \\
\text { Victoria Government in Australia. }\end{array}$ & on industry towards \\
\hline $\begin{array}{l}\text { Green Highway Part } \\
\text { by U.S.A (EPA and F }\end{array}$ & $\begin{array}{l}\text { For transportation infrastructure projects. This is mainly } \\
\text { sustainability performance metric for measurement systems that } \\
\text { provided guidance specific to building more sustainable transport } \\
\text { projects. }\end{array}$ \\
\hline $\begin{array}{l}\text { Green road tool } \\
\text { of Washington a }\end{array}$ & $\begin{array}{l}\text { Another infrastructure designing and construction rating system } \\
\text { available for sustainable infrastructure projects. A collection of } \\
\text { sustainability best practices which can be applied to any roadway } \\
\text { projects. }\end{array}$ \\
\hline $\begin{array}{l}\text { Green High } \\
\text { and [17] Ta }\end{array}$ & $\begin{array}{l}\text { Mainly sustainability categories are presentation of the } \\
\text { ecosystem, reduction of } \mathrm{Co}_{2} \text { emission, material resources, waste } \\
\text { reduction, and waste conservation. }\end{array}$ \\
\hline
\end{tabular}

Source: [1]

Table 3: Assessment Models for Building Environment

\begin{tabular}{ll}
\hline Sustainability Assessment Tools & Summary \\
\hline $\begin{array}{l}\text { Leadership in energy and environmental } \\
\text { design (LEED), developed by the US }\end{array}$ & $\begin{array}{c}\text { Green Building Rating System base on sustainability indicator } \\
\text { Green Building Council. }\end{array}$
\end{tabular}
Green Building Council.

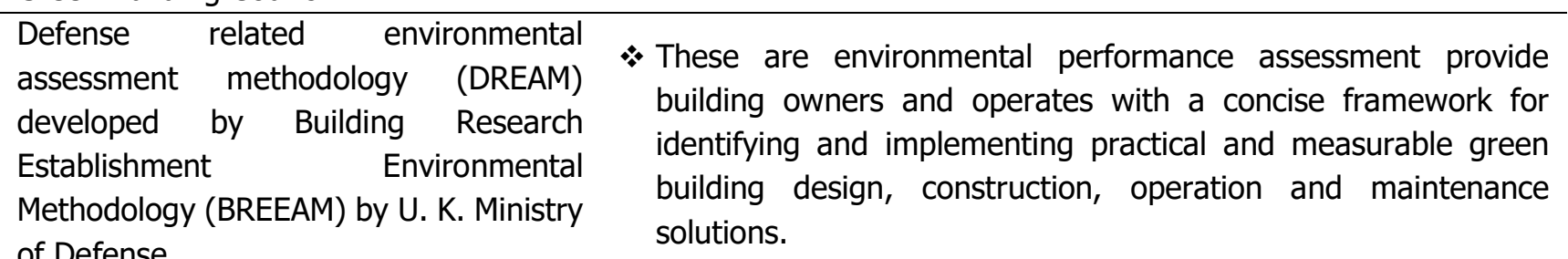
of Defense.

* Green star is a voluntary environmental railway system for buildings by the Green Building Council of Australia. The system

Green Star (Australia), developed by Green Building Council of Australia.

National Australia Built Environment Rating System Developed by Australia Government Initiative (NABERS).

Australia Building Green House Rating (AGBR). considers a broad range of practices for reducing the environmental impacts of buildings and to showcase innovation sustainable building practice, while also considering occupant health and productivity and cost savings.

* NABERS is a government initiative to measure and compare the environmental performance of Australia Buildings. It measures and communicates the actual impacts of a building owners, tenants and the community.

$*$ AGBR is a scheme that helps building owners and tenants across Australia beach mark the green house performance of their office premises. It takes into account of consumption of electricity, gas and other products such as fuels. 


\begin{tabular}{ll}
\hline Sustainability Assessment Tools & Summary \\
\hline \multirow{3}{*}{$\begin{array}{l}\text { Building sustainability index (Australia) } \\
\text { BASIX }\end{array}$} & $\begin{array}{l}\text { aASIX is online program that assesses a house or unit design } \\
\text { The main purpose is to ensure homes are built to be more energy } \\
\text { and water efficient. }\end{array}$ \\
\hline
\end{tabular}

Source: [1]

Table 4: Sustainable Transport Infrastructure Criteria and Indicators

\begin{tabular}{|c|c|c|}
\hline Economic & Environment & Society \\
\hline * User Rating & * Climate change emissions & * User ratings \\
\hline * Commute Time & * Other air pollution & * Safety \\
\hline * Employment Accessibility & * Noise pollution & * Fitness \\
\hline * Land use mix & * Land use impacts & * Community livability \\
\hline * Electronic Communication & * Water pollution & * Cultural preservation \\
\hline * Vehicle travel & * Habitat fragmentation & * Non-drivers \\
\hline * Transport cost efficiency & * Resource efficiency & * Affordability \\
\hline * Facility costs & * Water pollution & * Disabilities \\
\hline * Transport Diversity & & * NMT Transport \\
\hline * Congestion Delay & & * Children's travel \\
\hline * Travel costs & & * Inclusive planning \\
\hline * Cost efficiency & & \\
\hline * Delivery services & & \\
\hline * Commercial Transport & & \\
\hline * Crash costs & & \\
\hline * Planning quality & & \\
\hline * Mobility Management & & \\
\hline $\begin{array}{l}\text { Charges congestion } \\
\text { charges }\end{array}$ & & \\
\hline * Land use planning & & \\
\hline
\end{tabular}

Source: [1]

\subsection{Multi-criteria Decision Making Using Weighted Sum Model (WSM) for Sustainability Index or Aggregate.}

This section formulates the Mathematical Model for computing the sustainability index (Si) using the Weighted Sum Model (WSM). See table (5) sustainability Appraisal Decision Matrix.

\section{Table 5: Sustainability Appraisal Decision Matrix}

\begin{tabular}{|c|c|c|c|c|c|}
\hline \multirow[t]{3}{*}{$\begin{array}{l}\text { Design Alternatives Or } \\
\text { Options }\end{array}$} & \multicolumn{5}{|c|}{ Sustainability Criteria } \\
\hline & $\mathrm{Sc}_{1}$ & $\mathrm{Sc}_{2}$ & $\mathrm{Sc}_{3}$ & $\mathrm{Sc}_{4}$ & $\mathrm{~S}_{\mathrm{CN}}$ \\
\hline & $W_{1}$ & $W_{2}$ & $W_{3}$ & $W_{3}$ & $W_{N}$ \\
\hline$A_{1}$ & $\mathbf{a}_{1,1}$ & $a_{1,2}$ & $a_{1,3}$ & $a_{1,4}$ & $a_{1, N}$ \\
\hline$A_{2}$ & $a_{2,1}$ & $a_{2,2}$ & $a_{2,3}$ & $a_{2,4}$ & $\mathrm{a}_{2, \mathrm{~N}}$ \\
\hline$A_{3}$ & $a_{3,1}$ & $\mathrm{a}_{3,2}$ & $a_{3,3}$ & $\mathrm{a}_{3,4}$ & $d_{3, N}$ \\
\hline$A_{M}$ & aм,1 & ам,2 & aм,3 & ам,4 & \\
\hline
\end{tabular}

Source: [1 and 19]

Key $=S c i=$ Sustainability Criteria
$D i$ OR $A i=$ Design Alternative

$A i j=$ User assigned utility (scalar value) that measures the performance of $A i$ or $D i$ on $S c i$

The sustainability index $(S i)$ is defined as a crisp value that is an aggregated measures of performance of an alternative (such as a design alternative or option) along various sustainability dimensions (economy, environment and society). The underlying assumption here is the additive/cumulative utility of a given design, proposal (as measured by the sustainability index) depend on its individual utilities in the various decomposed elementals sustainability indicators. The assumption holds for most extent theories of utility and is particularly true of the concept of "generalized additivity" [18]. Also the use of weighted sum model assumes that the decision criteria can be expressed in the same unit of measure. This is achieved by using 
dimension less numerical scores (i.e. scalar quantity) in the sustainability appraisal process.

LetSIi (For $i=1,2,3 \ldots \ldots \ldots . . . M$ ) represent the final sustainability index (a crisp value) of design alternative (Di) OR (Ai) when all decision criteria - aij are consider. The next problem is how to computeSIi. There are different MCDM method such as Weighted Sum Model (WSM), Weighted Product Model (WPM), Analytical Network Process (ANP) and Analytical Hierarchical Process (AHP) [19] and [20]; [21] and [22]. Also referenced are [23] and [24] which contain detailed description of these methods. It is also considered sufficient for formulating an underpinning or solid base for mathematical model for quantitative sustainability appraisal [18].

The decision is further buttressed by the fact that a review of some completed case study of major projects and application of MCDM techniques in practice indicates that the weighted sum model is widely used for practical decision making in real life situations [18]. It is therefore considered valid enough to develop a mathematical foundation for sustainability appraisal in using the WSM method, the SI of design alternative $\mathrm{Di}$ or $\mathrm{Ai}$ is calculated using the following formula adopted from works of [23] and [18].

$$
\begin{aligned}
& S l_{i}=\sum_{i=1}^{N} \operatorname{dij}(i=1,2,3, \ldots M) \\
& \mathrm{S} l=\sum S l_{i}
\end{aligned}
$$

OR $A_{i}$ or $D_{i}\left(W S M^{\text {score }}\right)$ is defined as follows

$$
A_{i} W S M^{-s c o r e}=\sum_{j=1}^{n} \operatorname{aijWj}(i=1,2,3, \ldots M)
$$

$W_{j}=$ relative weight of importance of the criterion $C i$ and $a i j$ is the performance value of alternative $A i$ when it is evaluated in terms of alternative $A i$. For the maximization case, the best alternative is the one that yields the maximum total performance value.

Another underlying assumption in all MCDM methods is that the decision maker can quantify performance for a given design evaluation [18]. Therefore, the decision maker is considered to have sufficient knowledge and expertise (including experimental knowledge) in scoring the performance of design alternatives. Computational analysis is performed using these, assigned dimensionless score (scalar quantities). Hence, they are considered to be valid for the Mathematical model formulation (See appendix pages) which discussed KPIs that explained the decision-making criteria aij in equation (I).

\section{METHODOLOGY}

The research was conducted using a combination of structured questionnaire interviews with professionals working with public and private establishment, case study projects data, sustainable construction projects, environments and transportation/infrastructure projects, literature on sustainability research and questionnaires based survey for indicators. See figure 2 (Methodology of research approach).

The survey was conducted over 8 months which started from March - September, 2012 and questionnaires were distributed among the members for the purpose of this research. A total of 150 questionnaires were sent out or distributed to various professionals, consultants, clients and contractors in some selected geopolitical regions or zones in Nigeria. In order to achieve the objectives, the questionnaires were divided into 3 parts. The questionnaire was detailed and outlined the specific contexts of the research to the respondents. Part I elicited respondents background information (i.e. demographic data), while Part II focused on eliciting stakeholders' perceptions and prioritization on the sustainability of various proposed indicators for use in assessing transport and general infrastructure projects. The questionnaires were distributed using a combination of internal circulation through contact persons working in the identified Ministries, corporations or government organization through personal contacts, by e-mail and face-to-face interviews.

In part I, personal background questions which include information on respondents such as Global Reporting Initiatives (GRI) and United Nations Commissions on Sustainable Development (UNCED) and levels of use of involvement of such programs in practice. It was noticed that sustainability awareness has not been widely addressed in Nigeria over the years as observed, although, Nigerian government is making an effort for the implementation of sustainability concept in our infrastructure projects (transport and general infrastructure).

Too, no systematic appraisal tools and methods are use in practice level. Personal background information elicited also include the respondents experience and participation in sustainability driven infrastructure projects. Part II and III of the questionnaire asked respondents to give a score from $1-5$ against each of the selected indicators to determine their suitability in assessing sustainability of typical transport and 
general infrastructure projects. This translate as follows on the likert, scale $1=$ not suitable, $5=$ very suitable, with 3 being average suitable or value for acceptance of any indicator sustainability.

A total of 98 valid questionnaires were returned giving a response rate, while consultants and contractors gave lowest response rate. The percentage (\%) of unreturned questionnaires were $34.67 \%$ or (52Nos). North-East being the base of researcher has the highest response rate, Abuja and South-East, followed by second and third highest rates, while Lagos and South-South came fourth and fifth respectively (See tables 6, 7 and tables 8 and 9 .
Table 6: Returned questionnaire

\begin{tabular}{lll}
\hline Regions/Zones & $\begin{array}{l}\text { No. of } \\
\text { Returns }\end{array}$ & $\begin{array}{l}\text { Percentage Return } \\
(\%)\end{array}$ \\
\hline North-East & 33 & 22 \\
South-East & 17 & 11.33 \\
Abuja & 26 & 17.33 \\
Lagos & 11 & 7.33 \\
South-South & 11 & 7.33 \\
\hline
\end{tabular}

Source: Oraegbune [1]

Table 7: Unreturned questionnaires

\begin{tabular}{lll}
\hline Regions/Zones & No. Of Un-Returns & Percentage (\%) \\
\hline North-East & 6 & 4 \\
South-East & 7 & 4.67 \\
Abuja & 4 & 2.67 \\
Lagos & 4 & 2.67 \\
South-South & 31 & 20.67 \\
\hline & 52 & 34.67 \\
\hline
\end{tabular}

Source: Oraegbune [1]

Table 8: Showing summary of respondents' demographic data (Source: Analysis of survey data)

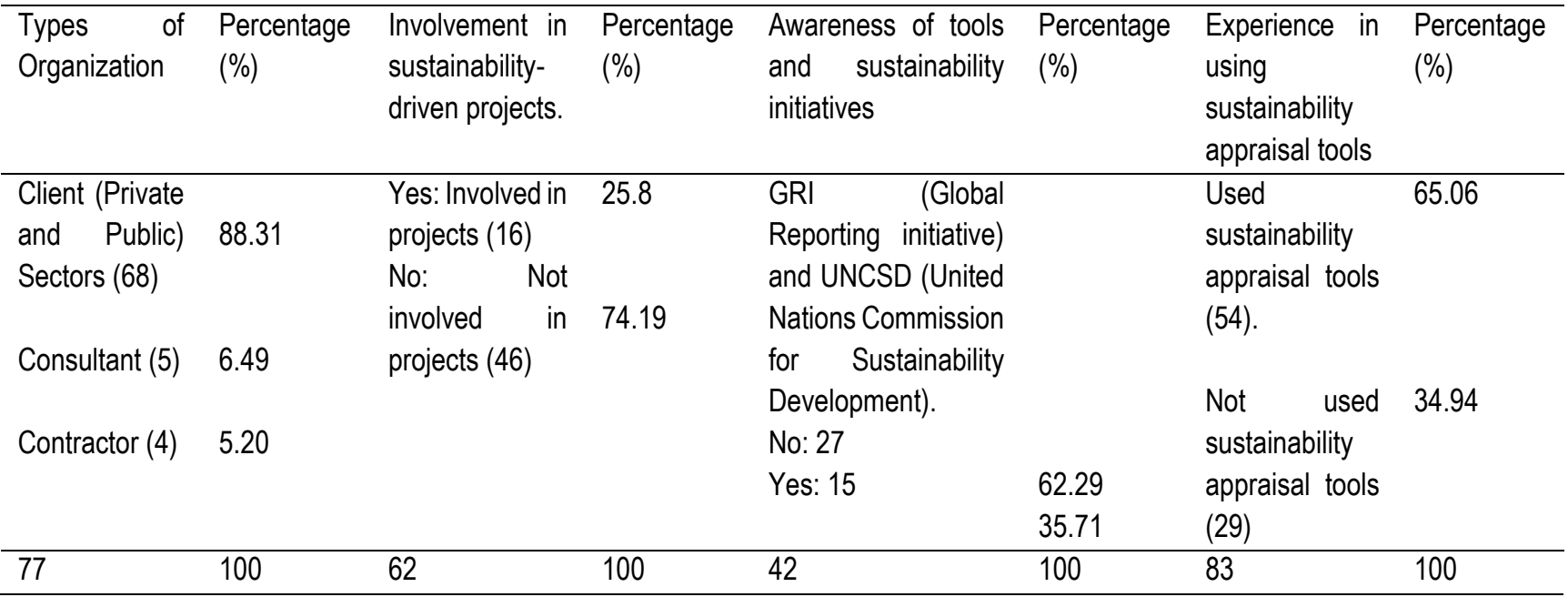

Source: [1]

Table 9: Showing summary of respondents' demographic data (Source: Analysis of survey data)

\begin{tabular}{lllllllll}
\hline $\begin{array}{l}\text { Position in the } \\
\text { Company }\end{array}$ & Nos. & $\begin{array}{l}\text { Percentage } \\
(\%)\end{array}$ & $\begin{array}{l}\text { Academic } \\
\text { Qualification }\end{array}$ & Nos. & $\begin{array}{l}\text { Percentage } \\
(\%)\end{array}$ & $\begin{array}{l}\text { Professional } \\
\text { qualifications }\end{array}$ & Nos. & $\begin{array}{l}\text { Percentage } \\
(\%)\end{array}$ \\
\hline $\begin{array}{l}\text { Permanent } \\
\text { Secretary }\end{array}$ & 1 & 1.30 & Ph.D. & 6 & 6.45 & FNSE & 3 & 3.30 \\
$\begin{array}{l}\text { Professor/Asst. } \\
\text { Professor }\end{array}$ & 2 & 2.60 & M.Sc./M. Engr. & 23 & 24.73 & COREN & 30 & 32.92 \\
$\begin{array}{l}\text { Director/Deputy } \\
\text { Director. }\end{array}$ & 15 & 19.48 & M. A & 1 & 1.08 & MNSE & 57 & 62.64 \\
$\begin{array}{l}\text { Assistant Director } \\
\text { Chief Engr./Asst }\end{array}$ & 6 & 7.79 & P. G. D & 6 & 6.45 & MNIOB/R.Builder & 5 & 5.50 \\
$\begin{array}{l}\text { Chief } \\
\text { Senior }\end{array}$ & 11 & 14.29 & B. Eng. & 57 & 61.29 & Others & 6 & 6.59 \\
$\begin{array}{l}\text { Engr./Principal } \\
\text { Engr. }\end{array}$ & 8 & 10.39 & OND & 1 & 1.08 & & & \\
Engineers & 7 & 9.09 & & & & & & \\
\end{tabular}




\begin{tabular}{lcllllll}
\hline $\begin{array}{l}\text { Position in the } \\
\text { Company }\end{array}$ & Nos. & $\begin{array}{l}\text { Percentage } \\
(\%)\end{array}$ & $\begin{array}{l}\text { Academic } \\
\text { Qualification }\end{array}$ & Nos. $\begin{array}{l}\text { Percentage } \\
(\%)\end{array}$ & $\begin{array}{l}\text { Professional } \\
\text { qualifications }\end{array}$ & Nos. $\begin{array}{l}\text { Percentage } \\
(\%)\end{array}$ \\
\hline $\begin{array}{l}\text { Principal Partners } \\
\text { M. D/C.E.O/ GM. }\end{array}$ & 4 & 5.20 & 9.09 & & & \\
$\begin{array}{l}\text { Project } \\
\text { Engr./Project }\end{array}$ & 2 & 2.60 & & & \\
$\begin{array}{l}\text { Coordinators } \\
\text { Chief Tech. } \\
\text { Officer/Supervisor }\end{array}$ & 4 & 5.20 & & & \\
$\begin{array}{l}\text { Senior Lecturer/ } \\
\text { Lecturers }\end{array}$ & 5 & 6.49 & & & \\
$\begin{array}{l}\text { Project Manager } \\
\text { Transport Planner }\end{array}$ & 2 & 2.60 & 2.60 & & & & \\
Engr. & 2 & & & & \\
Commercial & 1 & 1.30 & & & & \\
Manager. & 17 & & & & \\
\hline
\end{tabular}

Source: [1]

\subsection{Analysis of the Survey Results - Indicator Ranking}

This section uses descriptive statistics to present and discuss results of all- region and various questionnaire based indicators validation shown in appendix table.

The table shows the stakeholder's perceptions of key performance indicators in transport infrastructure sustainability tables which illustrated the main scores and ranks (out of maximum score of 5) for the proposed indicators. Cumulative ranking reflects stakeholders' views or perceptions. Table 10 and appendix table shows the summaries of respective indicators ranking positions for transportation infrastructure in All-region. Shown below are the maximum and minimum mean scores and rank values for the first and last indicators of various key sustainability domains of various regions.

Table 10: Maximum and Minimum Ranks

\begin{tabular}{|c|c|c|c|c|c|c|}
\hline & \multicolumn{2}{|c|}{ Economy [Mean], (rank) } & \multicolumn{2}{|c|}{ Environment [Mean], (rank) } & \multicolumn{2}{|c|}{ Society [Mean], (rank) } \\
\hline & Max & Min & Max & Min & Max & Min \\
\hline All Region & $\begin{array}{l}\text { Vehicle } \\
\text { travel } \\
\text { ranked } \\
{[3.90],(1)}\end{array}$ & $\begin{array}{l}\text { Prizing reform of toll gates } \\
\text { [2.88], (39) }\end{array}$ & $\begin{array}{l}\text { Land use } \\
\text { impact } \\
(3.10),(15) .\end{array}$ & $\begin{array}{l}\text { Water Pollution } \\
(3.10),(37)\end{array}$ & $\begin{array}{l}\text { Safety (3.67), } \\
(9)\end{array}$ & $\begin{array}{l}\text { Disabilities } \\
(2.83),(40)\end{array}$ \\
\hline Abuja & $\begin{array}{l}\text { Employment } \\
\text { accessibility } \\
(3.96),(1)\end{array}$ & $\begin{array}{l}\text { Prizing reforms e.g. } \\
\text { Tollgates and congestion } \\
\text { charges }(2.42),(39)\end{array}$ & $\begin{array}{l}\text { Resource } \\
\text { efficiency } \\
(3.42),(17)\end{array}$ & $\begin{array}{l}\text { Other air } \\
\text { pollution (2.46), } \\
(38)\end{array}$ & $\begin{array}{l}\text { Affordability } \\
(3.54),(11) \text {. }\end{array}$ & $\begin{array}{l}\text { Disabilities } \\
(2.35),(40)\end{array}$ \\
\hline Lagos & $\begin{array}{l}\text { Transport } \\
\text { diversity } \\
(4.60),(1)\end{array}$ & $\begin{array}{l}\text { Prizing Reforms e.g. Toll } \\
\text { gates and congestion } \\
\text { charges }(3.0),(34) \text {. }\end{array}$ & $\begin{array}{l}\text { Noise } \\
\text { pollution } \\
(4.30),(40)\end{array}$ & $\begin{array}{l}\text { Water Pollution } \\
(2.56),(40)\end{array}$ & $\begin{array}{l}\text { NM Transport } \\
(3.90),(11)\end{array}$ & $\begin{array}{l}\text { Disability } \\
\text { (2.60), (39). }\end{array}$ \\
\hline North East & $\begin{array}{l}\text { Commercial } \\
\text { transport } \\
(3.91),(1)\end{array}$ & $\begin{array}{l}\text { Prizing reforms e.g. Toll } \\
\text { gates/congestion charges } \\
(3.06),(37) \text {. }\end{array}$ & $\begin{array}{l}\text { Land Use } \\
\text { impacts } \\
(3.70),(7)\end{array}$ & $\begin{array}{l}\text { Habitat } \\
\text { fragmentation } \\
(3.19),(35)\end{array}$ & $\begin{array}{l}\text { Safety }(3.85) \\
(3)\end{array}$ & $\begin{array}{l}\text { Children's } \\
\text { travel }(2.91), \\
(40)\end{array}$ \\
\hline South East & $\begin{array}{l}\text { Cost } \\
\text { efficiency } \\
(4.06),(1)\end{array}$ & $\begin{array}{l}\text { Prizing reforms e.g. Toll } \\
\text { gates/congestion charges } \\
(3.13),(40)\end{array}$ & $\begin{array}{l}\text { Resource } \\
\text { efficiency } \\
(4.06)(1)\end{array}$ & $\begin{array}{l}\text { Prizing reforms } \\
\text { e.g. Toll } \\
\text { gates/congestion } \\
\text { charges (3.13), } \\
\text { (5) }\end{array}$ & $\begin{array}{l}\text { Community } \\
\text { livability }(4.00) \text {, } \\
(2)\end{array}$ & $\begin{array}{l}\text { Non-drivers } \\
(3.25)(39) \text {. }\end{array}$ \\
\hline
\end{tabular}

Source: [1] 
The Ten Most Critical Indicators in All-Region under Transportation Infrastructure Sustainability Criteria

\section{Sustainability Indicators/Criteria}

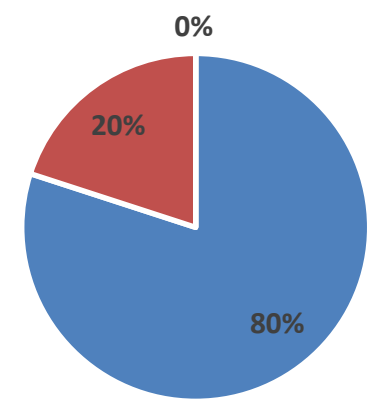

- Economic Sustainability;Vehicle travel (R1, M3.9),Transport delivery (R2, M3.90),Facility costs(R3, M3.83),Commercial transport(R4, M3.83),Travel costs(R5, M 3.75),Employment accessibility(R6, M3.73),User rating(R7, M 3.71),Cost efficiency(R8, M3.71)

- Societal Sustainability; Safety(R9, M3.71),Affordability(R10, M3.54)

- Environmental Sustainability

Fig. 2: Pie-chart for ten most ranked critical indicators in all- region

The ten most ranked critical indicators under the three sustainability criteria (economy, society and environment) are encapsulated into the pie-chart.

All-region criteria and its indicators are discussed here. Economy indicators are very active and are ranked higher than any other indicator in society and environmental sustainability. Out of the ten (10) critical indicators ranked, eight indicators from economy are ranked 1-8 (80\%), society indicators are ranked 9-10 (20\%), while environment indicators are not found within 1-10 ranked indicators (See piechart in figure 2 above).

This shows high level of economic activities in Allregion and awareness of sustainability issues under sustainability criteria of economy.

However, sustainability indicators ranking can vary from one region to another, depending on the activities/priorities and awareness of sustainability issues or understanding of a particular region. An indicator that is ranked high in one region can be ranked low in another region depending on the priority of the region (Please see appendix pages for general ranking in All-region).

\section{RESULTS AND DISCUSSION OF TRANSPORTATION INFRASTRUCTURE}

This discussion is encapsulated on triple bottom line sustainability criteria (economy, environment and society) and key performance or active indicators used in the questionnaire survey interview in Nigeria. All-Region Result; Represents the cumulative results of all other regions (Abuja, Lagos, North - East, and South-East). The author decided to use maximum and minimum ranking indicators from All-region under sustainable criteria for the discussion for the purpose of conciseness.

i. Economy: Indicators are ranked base on priority need of All-Region (Nigeria); for example, vehicle travel is ranked on topamongst all indicators (table 10). The ranking of the vehicle travel in Allregion (Nigeria) is a reflection of generic nature of road transport system among other mode of transportation and is faster developing more than other means of transportation as a result of massive road transport infrastructure development by various governments in Nigeria. This is an indication of popularity of road transport sector over other means of transport in Nigeria as shown in the cognitive map 
in Figure (3), where vehicle travel activity has direct causal impact on land use.

Prizing reforms for example (toll gate and congestion charges (39) has minimum ranking position (table 10) is a reflection or manifestation of real-life position in Nigeria. It is important to note that prizing reforms such as toll gate and congestion charges, if wellarticulated, is a source of revenue generation from transport infrastructure in Nigeria. In a developed country or countries where road and railway transport are under concession (i.e. under publicprivate partnership arrangement) roads and railways are developed and maintained by private companies who manage them for a number of years before transferring to government under build, operate and transfer (BOT).

However, in alignment with cognitive/reasoning map study in figure 4 above, prizing reforms (toll gate and congestion changes) will increase causal effect of transport infrastructure development.

ii. Environment: Indicators here are ranked base on the stakeholder's priority interests, for example land use impact is ranked (15) (see Tables 10 and the Appendix). Transport infrastructure development impact more on land due to extensive exposure, use and general degradation without adequate land protection. Land use impact has increase causal effect on community livability (see Figure 3).

Construction water pollution (37) under environmental criteria is ranked the least by the stakeholders (table 10 and appendix table), because of lack of awareness on the severity of water pollution and its implication on both sustainable environment and overall health system. The ranking therefore, did not present the real -life position of construction water pollution in Nigeria.

iii. Society: It is of particular interest to note that safety indicator was ranked (9) position among the key performance indicators in All-regions (Nigeria), (table 10 and appendix table) by the stakeholders. The ranking is a manifestation of reallife result because government and private sectors are becoming aware of the important of safety in our development process (i.e. transportation sector). A huge amount of capital is being invested in transport infrastructure system (road and railway) in order to improve safety for the workers and users in Nigeria. Safety of life during and after construction is among the top priority issues when developing transport sectors in any country.

Disabilities (indicator) is ranked least among other indicators under society criteria (table 10 and appendix table). The ranking is a reflection of the situation on ground. Transport infrastructure designers/developers have not given a serious thought during engineering design.

There is need for a constitutional clauses that will make it mandatory for every designer/developer to provide for the disabilities (when designing and during construction) for enhancing sustainable transport infrastructure in Nigeria.

\subsection{Sustainability Assessment: Procedures and Computational Methods}

Evaluating the sustainability of different design concepts/alternatives using numerical analysis involves three main steps. The process steps include:

(i) Determining the relevant applicable criteria and alternative design options.

(ii) Assigning numerical values (weight) to measure the relevant importance of these criteria for a given project and geographical location (i.e. country-specific) contexts. Each alternative is then appraised using the same basket of criteria, and

(iii) Processing numerical values (i.e. computational analysis) to determine the ranking of alternative design options along the various main sustainability indicators (See Appendix for practical application).

\subsection{Cognitive/Reasoning Map System as Decision Aid for Infrastructure Sustainability Appraisal.}

In a way to use the sustainability key performance project indicators (KPIs) in practical situations, it is necessary to understand/know the relationships and interactions between the various indicators at subdimensional levels. Reasoning/cognitive maps plays important roles in problem structuring. This is the same as quantitative methods in assessing sustainability decisions. Because of the structuring problems, this section develops reasoning and mapping models that show the cause and effect relationship between the various indicators. It uses the reasoning map to illustrate the complexities of the interaction between the various indicators. Knowing of the interaction between the various indicators. 
Knowing of the interactions would facilitate the sustainability appraisal process.

This appraisal is based on previous application among researchers to perform multi-criteria dimensional assessment of decision alternatives or options [25], [26] and [27] in [18] see Figures 6 for cognitive/reasoning map interpretation below:

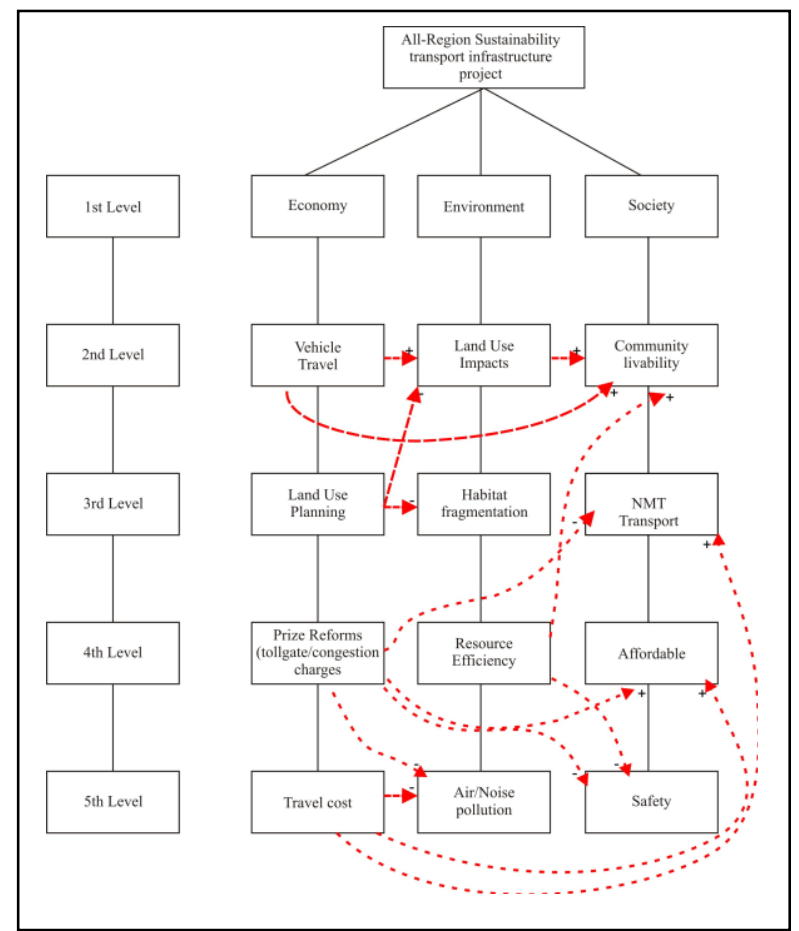

Figure 3: A hierarchy of key performance indicators or key active indicators (KPI/KAl) and cognitive/ reasoning map for infrastructure sustainability appraisal. Source: [1]

Key: - (dashed line) shows source - destination interaction between the indicators; + indicates increasing casual effect from source to destination; this indicates decreasing effect from source to destination.

i. Vehicle Travel: A vehicle travel activity (including development of transport infrastructure) will increase a direct cost or effect $(+)$ of impact on land use while land use impacts will also increase cost or effects $(+)$ on community livability.

ii. Land Use Planning: A good land use planning will increase a direct cost or effect $(+)$ of transport infrastructure development but will reduce associate cost or effect (-) of land use impacts. Efficiency land use planning will increase direct cost of transport infrastructure development but will as well reduce associate cost or effect (-) of habitat fragmentation. iii. Prize Reforms: Toll gate construction and congestion charges will increase direct cost or effect (+) of NMT transport. However, prize reforms (toll gate/congestion charges) will reduce the cost effect (-) of managing air/noise pollution in transportation industry and improves societal safety (i.e. will contribute to the improvement of sustainable environment and society).

iv. Resource Efficiency: Resources efficiency (resources such as solid-excavated materials and solid construction materials) if not well managed, will reduce community livability and safety, it will increase direct cost or effect $(+)$ of infrastructure development inadequacy or failure to sustain the existing infrastructure. It has tendency to increase (+) NMT transport activities and reduce $(-)$ affordability to travel.

\section{CONCLUSION:}

The study was made with a combination of structured interviews which targeted various stakeholders in infrastructure projects. An integrated sustainability assessment methods were used, which include procedures and computational methods. The Mathematical foundation models, Weighted Sum Model (WSM) in Multi-criteria Decision-method or model (MCDM) was used-base on Delphi method. The sustainability index $(\mathrm{Si})$ and crisp value are performance values for the design alternative ( $\mathrm{Di}$ or Ai) which used maximized yield as the best alternative design.

The study also discussed on key performance indicators for transport infrastructure sustainability, using sustainability appraisal in infrastructure projects (SUSAIP). Sustainability indicators are discussed base on All-regional result which is the cumulative results from four other regions. It was observed that some of the sustainability indicators are regional or project site-specific, while others are generic. The result of the questionnaire based indicator validation by the stakeholders indicates that some indicators can easily be influence due to unexpected and changes in societies or regional priorities. This also causes some intergenerational issues in the context of sustainability as a concept as collaborated with [19]. In this work, all developed indicators incorporate international recognized sustainability matrices for transport infrastructure (Economy, Environment and Society) triple bottom 
line (TBL) sustainability domains mentioned above and can be measured quantitatively during infrastructure development. It is also important to know that the result showed that there is no systematic method for the measurement of sustainability criteria and priority indicators in practice level before this study. However, there is an evidence of sustainability practice in isolation by the stakeholders. It was noticed that sustainability awareness has not been widely addressed in Nigeria over years, but presently government is making an effort for the implementation of the concept in our infrastructure projects.

Again, the cognitive map illustrated how vehicle travel indicator causal effect, affect the management and operation of land use impacts and community livability under sustainable transport infrastructure. The result also identified that walking and cycling are central to sustainability and community livability. These modes are low-cost and broadly available. It provides many environmental benefits; they are nonpolluting modes, their infrastructure requirements are less intense, their infrastructure requirements are less intense than other modes and they can often be supported through existing infrastructure. It also provide a variety of community benefits; they contribute to the health strengthen communities and support the vitality of retails districts and neighborhood.

This paper recommended gradual process and collaborating decision frameworks for sustainability evaluation and the mathematical foundation models which employed computational analysis in quantitative-based decision-making, crisp value and sustainability index for transport and general infrastructure projects assessment in Nigeria.

The findings which is base on the mathematical foundation analysis (through multi-criteria decisionmaking analysis) used Weighted Sum Model for analysis, while observation made shows immense or vast potential application of mathematical model in transport infrastructure implementation or practice level in Nigeria. This recommendation also collaborated with [19], which proposed the use of methodology and computational models, which the author suggested that could form basis for process automation in the broader context of sustainability appraisal and organizational knowledge management.
In addition, the research has the following implications as its contributions to policy and industry:

(i) Contribution to academic knowledge.

(ii) Contribution to the transport infrastructure and Construction industry

\section{REFERENCES}

[1] Oraegbune, M. O., An Appraisal of Transportation Infrastructure Sustainability, Framework, indicators, methods and tools, Ph.D. thesis, presented to the Department of Civil Engineering, University of Nigeria Nsukka, 2015

[2] Odeleye, J. A, An article on public private participation to Rescue Railway Development in Nigeria, published by Japan- Transport Review No. 23 PP (47 -49), 2000

[3] Federal Ministry of Planning, 1997.Future, 1997

[4] Mabogunje, A. I, "Preparing African cities for the Bond market" Urban Age, P. 2023, 1998

[5]Agenda 21 United Nation, Department of Economic and Social Affairs, Division of Sustainable Development, Retrieved June 15, 2006 from www.un.org/esa/sustdev/documents/agenda 21, 2004

[6] Brundtland, United Nation Report On, Our Common Press .Oxford,UK Oxford University, 1987

[7] Koo, D and Ariaratnam, S., Enhancement of sustainability in underground infrastructure development.Australian Society for Trenchless Technology ,24th No-Dig international Conference and Exibition, No-Dig Down under, Oct9-Nov2 2006,(pp33-42), Brisbane QLD ,Australia,2006

[8] JimHee, Kim, Yunk Kyung. Bae and Jin-Hyuk, Chung, International conference on Transport, Environment and Civil Engineering (ICTECE' 2012), August 25 - 26 Kuala Lumpir (Malaysis), 2012

[9] Litman, T., Well measured developing indicators for comprehensive and sustainable transport planning, Victoria Transport Policy Institute (www.vtpi.org);atwww.vppi.ord/wellmeas.pdf, 2007

[10] EuropeanCouncil of Ministers of Transport,"SustainableConstruction" April, 2004 brief.,2004 
[11] DESA, Development of Economic and Social Affairs (DESA). The role of the transport sector in Environmental protection background paper No. 15, CSD - 9, 16-27,2001

[12] CEEQUAL: (The Civil Engineering Environmental Quality Assessment and Awards Scheme)."CEEQUAL Scheme Description and Assessment and Awards Scheme) (2008). "CEEQUAL Scheme Description and Assessment Process Handbook" published online:www.ceequal.com.accessed on $8^{\text {th }}$ dec.2009,2008

[13] FIDIC (International Federation of Consulting Engineers). "Project Sustainability Management Guidelines". Geneva, Switzerland, 2001.

[14] Ugwu, O. O and Haupt, Key performance indicators for infrastructure sustainability. Acomparative study between Hong Hong and South Africa.Journal of Engineering, Design Technology .Vol.3. No.1June, SA, 2005

[15] AGIC (Australian Green Infrastructure Council), "GIC Infrastructure Sustainability Assessment Categories" fact sheet No. 2" www.agic.net.accesAsed8january, 2009

[16] Huang, R. Y and Yeh, C. H. "Development of an Assessment Framework for Green Highway Construction "Journal of the Chinese Institute of Engineers, Vol. 31, No.4, PP. 573-585, 2008

[17] Chiu, M. Y (2002). "A study of the Application of Ecological Engineering methods on the National Highway Construction". Master's thesis, graduate institute of Horticulture, National Taiwan University, Taipei, Taiwan; R.O.C., 2002

[18] Ugwu O.0;Kumaraswamy, M. M., Wong, A and $\mathrm{Ng}$, S.T., Sustainability appraisal in infrastructure projects (SUSAIP) part (1). Development of indicators and 'computational methods.Automation in construction 15(2006) 239-251. www.elsevier/locate/autcom, 2006

[19] Saaty, T. L., The Analytic Hierarchy Process. McGraw-Hill, New York, 1980

[20] Saaty, T. L., Decision making with the Analytic Hierarchy process. International Journal Services Sciences Vol. 1, No. 1. 2008
[21] Chan, S. J and Hwang, C. I, Fuzzy multiple decision-making, lecture notes in economies and mathematical systems Vol. 375, Springerverlag, New York, 1992

[22] Lootsma, F. A. Pardalos, P. M and Mano, S. H., On the evacuation and application of different scale for quantifying pairwise comparison in Fuzzy sets, journal of multi-criteria decision analysis 3 (B). PPs 133 - 155, 1994

[23] Fishburn, P. C., Additive utilities with incomplete product set: Applications to priorities and assignments, OSRAPublication, Baltimore, MD, USA, 1967

[24] Triantaphyllou, E., Multiple-criteria decision making: A comparative study, Dordreeht, the Neitherlands: Kluwer Academic Publisher (now springer). PP. 320/SBN0-7923-6607-7, 2000

[25] Bana e Costa, C. A, Esslin, L., Correa, E. C, and Vansnick, J. C., DSS in action, integrated application of a multi-criteria decision aid process, European Journal of Operational Research 113, (PP-315-335), 1999

[26] Kosko, B., Fuzzy cognitive maps, international Journal of machine studies 25, pp. 65-75, 1986

[27] Chan, S. J and Hwang,C.L., Fuzzy multiple decision making lecture notes in economics and mathematical system, vol.375, Spring average, New York, 1992

[28] Carteni, A; Parrota, L; Henke, I. Hedonic value of high- speed rail services: Quantitative analyses of the students' domestic tourist attractiveness of the main Italian cities . Transp.Res. A policy pract.2017, 100,348-365 (Cross Ref), 2017

[29] Ilaria Armando Carteni,ClonndaMolitierno and AssuntaErrico. Decision-making in the transport sector: A Sustainable Evaluation Method for road infrastructure. Published by Sustainability MDPI, 12(3), 764, 2020

[30] IntiS; Tandon, V., Application of fuzzy preference-Analytical Hierachy process Logic in Evaluating Sustainability of Transportation Requiring Multicriteria Decision Making. J.Infrasfructure.Syst.2017, 23 [Cross Ref], 2017 
APPENDIX: RESULTS SORTED - TRANSPORT INFRASTRUCTURE

ALL- REGIONS

\begin{tabular}{|c|c|c|c|c|c|c|}
\hline IDICATOR ID & Name & $\begin{array}{l}\text { Key Sustainability } \\
\text { Item }\end{array}$ & MEAN & STDEV & RII & RANK \\
\hline 6 & Vehicle Travel & Economy & 3.90 & 0.92 & 0.78 & 1 \\
\hline 7 & Transport Diversity & Economy & 3.84 & 1.04 & 0.77 & 2 \\
\hline 11 & Facility Costs & Economy & 3.83 & 0.95 & 0.77 & 3 \\
\hline 15 & Commercial Transport & Economy & 3.83 & 0.95 & 0.77 & 4 \\
\hline 9 & Travel Costs & Economy & 3.75 & 1.03 & 0.75 & 5 \\
\hline 3 & Employment Accessibility & Economy & 3.73 & 0.96 & 0.75 & 6 \\
\hline 1 & User Rating & Economy & 3.71 & 0.79 & 0.74 & 7 \\
\hline 12 & Cost Efficiency & Economy & 3.71 & 0.94 & 0.74 & 8 \\
\hline 31 & Safety & Society & 3.67 & 1.07 & 0.73 & 9 \\
\hline 36 & Affordability & Society & 3.62 & 0.91 & 0.72 & 10 \\
\hline 17 & Planning Quality & Economy & 3.61 & 0.95 & 0.72 & 11 \\
\hline 14 & Delivery Services & Economy & 3.61 & 0.96 & 0.72 & 12 \\
\hline 2 & Commute Time & Economy & 3.60 & 0.89 & 0.72 & 13 \\
\hline 20 & Land Use Planning & Economy & 3.60 & 0.94 & 0.72 & 14 \\
\hline 25 & Land Use Impacts & Environment & 3.58 & 0.87 & 0.72 & 15 \\
\hline 13 & Freight Efficiency & Economy & 3.57 & 0.99 & 0.71 & $` 16$ \\
\hline 4 & Land Use Mix & Economy & 3.57 & 0.81 & 0.71 & 17 \\
\hline 10 & Transport Cost Efficiency & Economy & 3.56 & 0.94 & 0.71 & 18 \\
\hline 16 & Crash Costs (measured in per capita) & Economy & 3.55 & 1.10 & 0.71 & 19 \\
\hline 29 & Resource Efficiency & Environment & 3.55 & 1.03 & 0.71 & 20 \\
\hline 24 & Noise Pollution & Environment & 3.51 & 1.15 & 0.70 & 21 \\
\hline 33 & Community Livability & Society & 3.51 & 1.05 & 0.70 & 22 \\
\hline 18 & Mobility Management & Economy & 3.49 & 0.95 & 0.70 & 23 \\
\hline 8 & Congestion Delay & Economy & 3.47 & 1.19 & 0.69 & 24 \\
\hline 30 & User Rating & Society & 3.44 & 0.95 & 0.69 & 25 \\
\hline 34 & Cultural Preservation & Society & 3.43 & 0.95 & 0.69 & 26 \\
\hline 23 & Air Pollution & Environment & 3.40 & 1.18 & 0.68 & 27 \\
\hline 28 & Habitat Fragmentation & Environment & 3.38 & 1.08 & 0.68 & 28 \\
\hline 32 & Fitness & Society & 3.37 & 1.01 & 0.67 & 29 \\
\hline 40 & Inclusive Planning & Society & 3.36 & 0.94 & 0.67 & 30 \\
\hline 5 & Electronic Communication & Economy & 3.31 & 1.05 & 0.66 & 31 \\
\hline 27 & Habitat Protection & Environment & 3.28 & 1.08 & 0.66 & 32 \\
\hline 38 & NMT Transport & Society & 3.19 & 1.03 & 0.64 & 33 \\
\hline 39 & Children's Travel & Society & 3.18 & 1.08 & 0.64 & 34 \\
\hline 21 & Climate Change Emissions & Environment & 3.18 & 1.24 & 0.64 & 35 \\
\hline 22 & Other Air Pollution & Environment & 3.13 & 1.23 & 0.63 & 36 \\
\hline 26 & Water Pollution & Environment & 3.10 & 1.24 & 0.62 & 37 \\
\hline 35 & Non-drivers & Society & 3.05 & 0.97 & 0.61 & 38 \\
\hline 19 & $\begin{array}{l}\text { Pricing Reforms (e.g. Toll Gate } \\
\text { Charges, Congestion Charges etc) }\end{array}$ & Economy & 2.88 & 1.25 & 0.58 & 39 \\
\hline 37 & Disabilities & Society & 2.83 & 1.16 & 0.57 & 40 \\
\hline
\end{tabular}

